\title{
最近の歯学
}

\section{5. 口腔細菌}

\section{歯石子細 菌}

口腔細菌学教室 近藤亘

歯石の沈着を文配する因子上して，唾液性の因子と細 菌性の因子が考えら䢵ている。唾液性の因子としては, 唾液のコロイド状態の変化, アンモニアの産生あるいは 炭酸ガスの品失による唾液のアルカリ化, Phosphatase の作用による無機燐酸濃度の増加が重要なものとして論 じられているが末だに一致した見解が生れていない。 (Leung, Jensen, 1958) ${ }^{11}$ 。

この度は歯石と細菌の関倸について最近の報告を二三 紹介したい。

組織学的に観察した場合, 歯石の中法必ず数多くの 細菌. 主として系状の Leptotrichia, Actinomyces が含

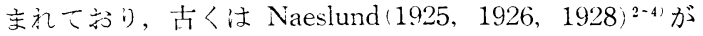
試騃管内で Actinonyces き培養して結石を作ることに 成功して以来. こ礼らの細菌が歯石沈着に重要な意味を 持つであろうと考えら机てきた。事実，無菌的にした唾 液内では人工的な歯石形成は起らないし(Bibby 1935) ${ }^{5)}$, Actinomyces が強いPhosphatase activity を示すことは Plaque 内での歯石沈着老説明するに有利な事実であり (Ennever, Warner 1952) ${ }^{6}$, また in vitro の実験で Plaque から分離された長系状菌（恐らく Leptotrichia） の菌体内に Ca-hydroxyapatite の形成されることが証明 されている(Ennever, 1960) ”。

これらの報告は何机も歯石上細菌上が不可分の関係に あるここを示唆しているが，最近これとは異つた見解が 報告されている。

Wasserman, Mandel, Levy (1958) ${ }^{8:}$ は Celluloid strip 在人間の歯の歯頸部に捲きつけて2〜3 日間放置し, Celluloid の表面に Bacterial plaque. を着生させ，それ 在人工的な石灰化溶液 $(\mathrm{pH} 7.0) に 4 \sim 6$ 日間, $37^{\circ} \mathrm{C}$ で incubate して Plaque の歯石形成を調べた。この条件 で. Celluloid 表面の Plaque は4 日間で歯石の形成を 起すが，その際 Plaque を子小 $10 \%$ Formalin で 15 分間処理しておいても同じように歯石が形成されること 虑認めた。またPlaque を着生させた Celluloid の代り にActinomyces israelii の寒天平板上の集落で実験した 場台も同様であつ下集落をその儘石灰化液につけた場合 にも，10\%の Formalin だ処理した後にも石灰化が起 るこ上を認めた。この実騃から Plaque における細菌の Viability は歯石形成上は無関倸で，歯石形成こお沙る 細菌の意味は, 細菌の酵素活性によるよりも, むしろ菌 体自身の Ca 塩の沈着を起させる性質によると考えられ る。また阻害実験の結果, 石灰化液に Hyaluronidase を 加えると歯石形成が著しく阻害されることが証明され
た。このことは生体組織の石灰化に当つて Carbohydrate-Protein Complex が重要な役割安演ずるこ上が知 られているので，歯石形成の場合にもHyaluronidase が この Complex の Carbohydrate 部分を分解することに よつて歯石の形成が阻害されるのであるうと考察されて ける。

Gorizales, Sognnaes $(1960)^{9}$ の電子顕微鏡的な 観察に よれば，歯石の石灰沈着は最初主上して細菌上細菌の間 (Matrix)に起り, 後になつて菌体内に石灰沈着が起るら しい。著者等は Plaque 内の細菌がどの程度まで Matrix (恐らく Salivary mucus)の石灰化に関与するかは判ら ないが,この Matrix の性状は Apatite nucleation を理 解するに当つて極めて重要な意味を持つている上述べて いる。

Fitzgerald, McDaniel (1969) ${ }^{10}$ は Germ-free rat に歯 石沈着の起ることを報告している。沈着物の性状は革様 の硬さのものから硬くて脆いものまであつて全て Alizarin red-Sによく染まる。沈着場所は上顎第一大臼歯の 近心面に限られていて, 時々この歯の Second cusp の煩 面にも見られる。その大きさや構造は普通の Non-germ free rat に見られる歯石と変らない, 革様の硬さの沈着 物は結晶性物質が少いため偏光顕微鏡で複屈折性を証明 することは困難であるが，6匹の Rat から硬くて脆、沈 着物を集めてX線回折を行つた結果 Apatite であること が証明されたという。この結果は歯石形成は必ずしも細 菌つ存在を必要としないこ上意味している。

\section{文献}

1) Leung, S. W. and Jensen, A. T. : Int. dent. J. $8: 613,1958$.

2) Naeslund, C: Acta. Path. Microbiol. Scand., $2: 244,1925$.

3) Naeslund, C: Acta. Path. Microbiol. Scand., $3: 637,1926$.

4) Naeslund, C: Acta. Path. Microbiol. Scand., $6: 78,1928$.

5) Bibby, B. G. : Dent. Cosmos, $77: 668,1935$.

6) Ennever, J. J. and Warner, B. W. : J. Dent. Res. 31 : 25, 1952.

7) Ennever, J. J. : J. Periodont, 31 : 304, 1960.

8) Wasserman, B. H., Mandel, I. D. and Levy, B. M. : J. Periodont, $29:$ 144, 1958.

9) Gonzales, F. and Sognnaes, R. F. : Science., $131: 156,1960$.

10) Fitzgerald, R. J., and Mc Daniel, E. G.; Arch. oral. Biol. 2 : 239, 1960. 